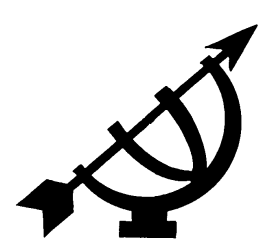

\title{
An epistemology of engagement ${ }^{1}$
}

\author{
Michael Heyns \\ School of Philosophy \\ Potchefstroom campus \\ North-West University \\ POTCHEFSTROOM \\ E-mail: michael.heyns@nwu.ac.za
}

\section{Abstract \\ An epistemology of engagement}

Within the viewpoint of representationalist epistemology it is assumed that objects can be represented in the mind or in language by rebuilding images of these objects from foundational ideas. In this article I examine the resistance to this depiction in an ongoing debate between Rorty and Taylor. Taylor argues that we should overcome the disengagement in what he sees as representationalism's dualism of two mutually exclusive assumptions. The first assumption is the solipsist notion that our ideas can be formed without reference to the world outside the mind. According to the second tenet, however, it is paradoxically also assumed that these inner ideas are representations of the world. Because Rorty mainly targets the element of foundationalism in representationalism, he seems to argue that all we are able to know are our perspectives. I argue (in line with Taylor's line of thought) that

1 Opgedra aan 'n gewaardeerde leermeester. Ek het 'n heelwat vroeëre weergawe van hierdie artikel 'n ruk voor sy dood vir "prof. Theo" gegee om sy kommentaar te hoor. Hy het een aand spesiaal na my huis gekom en vir meer as ' $n$ uur baie intensief ' $n$ aantal belangrike punte met my deurgepraat. ' $n$ Mens kan nie anders as om in hierdie optrede, wat homself niks in die sak sou bring nie, 'n stuk akademiese integriteit en medemenslikheid raak te sien; 'n houding tipies van sy lewe as akademikus. / Dedicated to an esteemed tutor. Some time prior to his death I submitted an earlier version of this article to "Prof. Theo" for comments and recommendations. In response to this request he made a special effort by coming to my home and spending more than an hour in which he discussed certain aspects of the article in depth with me. This way of doing that would not benefit him in any way reflects an attitude of scholary integrity and a sense of humane fellow-feeling typical of his life as academic. 
this view implies that Rorty leans towards solipsism and thus remains under the spell of representationalism. Taylor, on the other hand, partially accepts the strong grip of perspectives on our knowing but simultaneously devises the concept of "preunderstanding" to get beyond perspectivism. I argue that Taylor's thinking may still leave us with a mild foundationalism. However, the holism he assumes, can be used in a re-formed way to bring us a step closer to overcoming the representationalist dualism, and to steer us in the direction of an epistemology of engagement.

\section{Opsomming}

\section{'n Epistemologie van verbondenheid}

Binne die raamwerk van die representasionalistiese epistemologie word veronderstel dat objekte in denke of in taal weergegee kan word deur beelde van hierdie objekte vanuit "fondamentele" idees te herbou. In hierdie artikel word die weerstand teen hierdie voorstelling ondersoek in die voortgaande debat tussen Rorty en Taylor. Taylor betoog dat ons nie-gebondenheid moet oorkom in wat hy beskou as die representasionalisme se dualisme van twee wedersyds uitsluitende veronderstellings. Die eerste veronderstelling is die solipsistiese idee dat ons idees gevorm kan word sonder enige verwysing na die wêreld buite die denke. Maar, volgens die tweede veronderstelling, kan ook paradoksaal veronderstel word dat hierdie innerlike idees representasies is van die wêreld. Omdat Rorty se teiken hoofsaaklik die element van "fondamentalisme" in representasionalisme is, lyk dit of hy betoog dat al wat ons in staat is om te ken ons perspektiewe is. Ek beredeneer (in ooreenstemming met die denklyn van Taylor) dat hierdie sienswyse impliseer dat Rorty neig na 'n solipsisme en dat hy dus steeds onder die invloed van die representasionalisme verkeer. Taylor, aan die ander kant, erken gedeeltelik die greep wat perspektiewe op ons kenne het, maar ontwikkel terselfdertyd die konsep "voorverstaan" om perspektiwisme te ontkom. Ek beredeneer die stelling dat Taylor se denkwyse ons steeds met 'n matige fondamentalisme laat. Die holisme wat hy veronderstel, kan egter op 'n hervormde manier gebruik word om ons 'n tree nader te bring aan die oorkom van 'n representasionalistiese dualisme en kan ons dus in die rigting van 'n epistemologie van verbondenheid stuur.

\section{Introduction}

The epistemological tradition associated with modernism attempted to distinguish between true knowledge and appearance, a distinction that this tradition linked to a dualism between knower and knowable. 
The way to overcome this dualism, modernists argued, is to attain exact representations of the knowable in the mind or language of the knower - hence the label representationalism for this tradition. The way to create these true representations lies in the ability of our mind or language to gather foundational precepts or ideas about things and then to build a representation from these building blocks. In the twentieth century, however, massive resistance against this view became evident because it failed and in fact increased rampant scepticism and agnosticism about the possibility of true knowledge.

The direction this critique should take became a major issue of debate between Richard Rorty and Charles Taylor. The nature of an alternative to representationalism will also be the central question of this article. My suggested answer will entail that a portrayal of reliable knowing will include an inescapable engagement between knower and knowable. It will be argued that an over-emphasis of a process of representation, which is built on self-created foundational concepts, will end in a dualism between knower and known. Representation can nevertheless be part of the process of knowing. In fact, an epistemology of engagement will consist of many ways of knowing a multi-dimensional knowable, which means that this epistemology comprises a "thick" process of knowing.

I will argue that Rorty's thinking about the possibility of knowing is characterised by a strong perspectivism. It is of course crucial for the recognition of a Christian viewpoint in for instance science, that the idea of one's perspective as an important influence on knowing be recognised. However, I will argue that Rorty's strong perspectivism militates against engagement with the knowable and steers him in the direction of solipsism. The worldview direction I will take is very well articulated by Wolters (1988:29) when he discusses the view of some Christians who argue that the "human powers of cognition have been so corrupted by sin as to make them unable to discern God's will for such areas as art, economics, or politics". Against this pessimism Wolters argues that these views "either fail to do justice to the constancy of God's will for creation (or to its revelatory power) or else they downplay the renewing power of Jesus Christ in restoring our faculty of discernment".

Despite a residue of foundationalism in his thinking, Taylor's moderate realism, his plea for a self of engagement, as well as his holism opens the door to a view of knowing that favours engagement. Although the major drift of Rorty's perspectivism is against engagement, his view of a multi-relational and multi- 
functional knowable nevertheless (and inadvertently) opens up possibilities for a knowing process based on engagement.

As positive contribution towards the development of an epistemology of engagement I shall take at the end of each subsection the transcendental step of formulating a condition for knowing reality that can be inferred from important points in the debate between Rorty and Taylor.

\section{The human perspective without solipsism}

The aim of knowledge, according to the viewpoints of representationalism, is to give an exact representation of reality in the mind or in language, a representation that can then be labelled the truth about that reality. However, says Rorty (1999:37-38), "truth" cannot be the aim of inquiry. He gives two reasons for this claim:

- Firstly, such an aim would only be warranted "if there were such a thing as ultimate justification - justification before God, or before the tribunal of reason". There can, however, not be such a tribunal that "envisages all the alternatives to a given belief".

- Furthermore, Rorty believes in a "Darwinian picture of the world", which tells us there is no aim for biological evolution; "the species" that evolution has as its aim, do not exist. Similarly "truth" as the aim of inquiry also does not exist. The philosophical aim to say something about "the nature or limits of human knowledge" is therefore also impossible.

The aim of inquiry, Rorty (1991:96-99) says, is merely to list the "more important beliefs which we hold at the current stage of inquiry". For Rorty to ask, "But is there really any such thing?" is an "awkward way of putting the question". The question should rather be "Are there other beliefs which we ought to have", a question which can only be answered "by enumerating and recommending such other beliefs". This view represents the core of what I shall refer to as Rorty's perspectivism - although, as I shall point out, Rorty tries to be more subtle than this apparently crude version of a perspectivism that hovers on the brink of solipsism.

Taylor, on the other hand, insists that we somehow do get in contact with reality and do not forever remain within our perspectives. He (Taylor, 1991:268-269) uses the example of the "existential proposition", that "there are no chairs in this room". In this case, he says, there will be "no serious temptation to deny that the no chairs claim will be true or false in virtue of the way things are". And, he 
adds, similar "things could be said of the claim that there are electrons or quarks".

Rorty (1995:22-23) argues that this claim is not obvious. He sees two ways to interpret "in virtue of the way things are":

- The first is to see it as "in virtue of the way our current descriptions of things are used and the causal interactions we have with those things".

- The second is "simply in virtue of the way things are, quite apart from how we describe them". Rorty rejects the latter because he cannot see how we can make a distinction between "our describing activity, our use of words, and the role of the rest of the universe in accounting for the truth of our true beliefs". In other words, we should drop the "attempt to sort our propositions by whether they are 'made' true by 'the world' or by 'us"'.

Despite Rorty's attempt to uphold both our "descriptions of things" and the "causal interactions" we have with reality, one gets the impression that he ultimately chooses to concern himself with only the perspective side of knowing (i.e. description).

It is nevertheless important to take note of the two sides to knowing (perspective and interaction with reality) that Rorty points us to. His emphasis on perspectives confronts us with the inescapable necessity also to take the perspective side always into account. Dreyfus (2004:71-72) emphasises this point with the observation that the number of chairs in the room depends on the interests of the person counting them. If someone for instance wants to seat an audience right at a given moment, he should not count the broken chairs. This still means that truth is the "correspondence between our description of the facts relative to our interests and the facts themselves".

That our interests and thus perspective play an important role in our knowing is a claim that Taylor will readily agree with as we shall see. However, Rorty, mostly seems to have in mind that perspective is the only thing that plays a role. He (Rorty, 1999:48-50) assumes for instance that "everything 2 is a social construction" and that "all awareness is a linguistic affair", which means our linguistic descriptions "will always be a function of our social needs". The

2 The italics in this paragraph are mine - M.H. 
latter view implies that there cannot be a distinction between knowing things and using them. The only possible distinction is between a "less useful" and a "more useful" description of the world. Furthermore, the emphasis on articulation implies, Rorty (1999:50) says, that "we shall never be able to step outside of language, never be able to grasp reality unmediated by a linguistic description".

These reductionist pronouncements give Rorty the image of a solipsist exponent of postmodern 3 perspectivism. Moreover, while denying individual solipsism, Rorty (1991:101) insists in typical postmodern fashion that "the community of inquirers" to which a knower belongs, gives her most of her beliefs. This community however "is stuck, for the time being, within its own vocabulary". This view means, Rorty (1999:xxv) says, that we cannot see truth as the goal of inquiry. The goal of inquiry is rather "to achieve agreement among human beings about what to do to bring about consensus on the ends to be achieved and the means to be used to achieve those ends". The individual self of modernism who lives in the shadow of solipsism, seems to be merely substituted by a postmodern collective self that remains in the same shadow. 4

This picture can leave one with the impression that justification is merely a matter of giving reasons to satisfy our peers. This view of justification makes justification nothing more than a social practice with only the authority of the society that does the justification. The critic will ask in this case, says Gutting (2003:47): "How can genuine knowledge be based simply on what seems right to some particular group?". Gutting (2003:49-52) advises Rorty to take into account that consensus is usually the outcome of a complicated process of "successful reason-giving", which includes a thorough investigation and critique of the evidence. Instead Rorty seems to opt for a purely "decisionist (or voluntarist) view of knowledge". However, if Rorty also accepts "careful argumentation" as condition, his view that there is no other way for us to justify beliefs than the social practice of giving reasons, will still be regarded by Gutting as a "coherent and plausible alternative to what representationalism has to offer". What Gutting proposes in this respect remains, however, within the

3 Braeckmans (1997:167-169) describes postmodern epistemology as an intertextuality that becomes a hyperreality, which suggests that reality cannot touch us, or does not even exist.

$4 \quad$ Hollis (1991:247-249) in fact argues that eventually in Rorty the "I' of cogito is being replaced with a 'we' of conversation". 
bounds of proceduralism, $\mathbf{5}$ which still do not assume an inescapable engagement with reality.

Taylor is therefore justified to have "the dark suspicion" that Rorty is still being "in the thrall" of modernist representationalism when he tells us that "we all only know the world mediately, through a screen of representations which each of us forms in the mind". This means that "stubborn differences in representation would be unarbitrable, because no one would ever be able to get behind our pictures into contact with the world out there".(Taylor, 1991:260). Representationalism always produces the suspicion that maybe the world does not really conform to the representation (Taylor, 2003:162). Thus, when the representationalist picture of how we establish truth fails, all that is left is the self-enclosed subject, "out of contact with the transcendent world". From this solipsism it is a small step to antirealism. If we can never know whether our ideas or language correspond to the extra-knower reality, then how can we speak of the existence of this reality in the first place? In the end it seems as if representationalists and Rorty find themselves in the same "dialectical universe". Both will try to answer the fear that our representations are only in our heads (Taylor, 2003:168).

A first condition for an epistemology of engagement: We need to accept the idea that all knowledge is a perspective determined by our interests, aims and beliefs. However, if we take Taylor's critique of Rorty seriously, perspective should not condemn us to the assumption of solipsism that the idea of engagement between knower and the knowable is an equally important dimension of knowing.

\section{Reality without the un-engageable}

Taylor (2003:174-175) maintains that although far-reaching differences sometimes exist in our perspectives, agreement on representations can be "within the context of a basic engagement with/understanding of the world". It is because we have contact with a "common world" that we are able to speak to one another and have "something to point to in disputes about reality".

5 See subsection 5 dealing with "Representation/perspective without the disengaged self" for a description of proceduralism. 
A good example of this common contact with reality is Taylor's concept import as something in a situation that one is able to deal emotionally with. Taylor (1985a:47-51) acknowledges that an emotion is not simply an objective description of the situation. It is, on the other hand, also not true that emotion is based on pure perspective. There is rather a "sense" of a situation as having a certain property about which we cannot be neutral. We experience a situation as "bearing a certain import". An import is the "way in which something can be relevant or of importance to the desires or purposes or aspirations or feelings of a subject". It brings something subject-independent to the subjective interests of humans. He therefore says that "to ascribe an import is to make a judgement about the way things are, which cannot simply be reduced to the way we feel about them". ${ }^{6}$

The claim that there is something perspective-independent in the knowable may seem like the representationalist attempt to know something that severely resists knowing and thus can be a token of the dualism between knower and knowable. Rorty (1995:23) indeed accuses Taylor of still believing in "Kant's notion of 'things-inthemselves"'. Taylor, he says, assumes for his theory of correspondence that we posit something like "the world as it is in itself" or "the features which a thing has intrinsically, independent of how we describe it". 7

The weakness Rorty primarily attacks in representationalism is the latter's foundationalism. According to Rorty we have no perspectivefree precepts from which to build our representations. This point of attack is probably closely connected to an anti-essentialism. This is, according to Rorty (1999:50), the attempt to know an object with the aim to be "related to something intrinsic" to that object. But, he says, there is no "inner core of X and a peripheral area of X". There can thus be no such thing as a "description which matches the way $X$ really is, apart from its relation to human needs or consciousness or language". Rorty (1999:58) primarily targets the essentialist claim that objects have "non-relational, intrinsic, essences which may, alas, be beyond our ken". Rorty (1999:58) therefore remarks that the "Kantian lament that we are for ever trapped behind the veil of subjectivity is merely the pointless, because tautologous, claim that

6 Cf. similar descriptions by Taylor (1985a:101, 197-198; 1985b:55).

7 Cf. a similar evaluation by Rorty (1980:41). 
something we define as being beyond our knowledge is, alas, beyond our knowledge".

Taylor (1980:47-48; 1995:215) complains that Rorty rather targets the "Kantian distinction between things-in-themselves and the phenomenal" than his (Taylor's) view. 8 Kant distinguished "things as they are outside of any relation to human knowledge (in-themselves) from things as they are in relation to human knowledge (for us)". Taylor emphasises that by "the very definition, we can never achieve knowledge of such a world-in-itself" (Taylor, 1980a:47-48). ${ }^{9}$ Taylor insists that "Kant's notion of the thing-in-itself is very much a creation of the epistemological tradition". It was created by the "belief that what we are immediately aware of is appearances or representations". In distinction, we see the thing-in-itself "as something which we can by definition have no experience of". However, if we can disregard the influence of this general presupposition, the idea of the "thing-in-itself makes no further sense". Taylor therefore expresses his "puzzlement" that "talk of thought corresponding to reality, even to a reality independent of my representations, should be linked to the invocation of a thing-initself" (Taylor 1991:270-271).

The point Taylor suggests seems important. This point entails that a perspective that claims to be in contact with reality does not need to assume an essentialist ontology in which essences are understood to be substances that are in principle unrelated and unknowable but nevertheless underlie everything that exists. Moreover, such an essence (essentialism) usually comprises a reduction of the totality of reality to a single aspect thereof. This aspect is then seen as the core that underlies everything that exists. The alternative is thus to look at reality through the lens of a multi-aspectuality. (I shall return to this theme.)

A second condition for knowing as engagement: If we want to avoid the looming solipsism (and reductionism) of representationalism and perspectivism we need to see reality through a nonessentialist lens which means that the aim of knowing is to engage Taylor (1985:219).

9 It is questionable if Rorty and Taylor are really fair to Kant for, as one of the referees of this article remarked: "Kant het egter besef dat daar 'n denkvorm moet bestaan waarin die (ondenkbare) 'Ding-op-sigself' gedink kan word - en dit is vir Kant die rede-ideë (grensbegrippe)." 
with the multitude of aspects of reality that are knowable and are thus engageable.

\section{Representation/perspective without dualism}

Taylor (1989b:474) claims that the fundamental notion of representationalism is "an ultimately incoherent amalgam" of two tenets.

- The first tenet is that of solipsism: ideas are "self-enclosed, in the sense that they can be accurately identified and described in abstraction from the 'outside' world".

- The second tenet is that of representation: our ideas "nevertheless point toward and represent things in that outside world".

Taylor, however, points out that it is important to note that these two tenets exclude each other. This exclusion or non-contact, one can add, is the main feature of the dualism inherent to representationalism.

Rorty's (1991:100) solipsism and thus imminent anti-realism mean that he is "tempted to say that there were no objects before language shaped the raw material (a lot of ding-ansichy, all-contentno-scheme, stuff)". He wants to discard even the "ding-ansichy" stuff and to create a "hall-of-mirrors effect - in getting us to stop asking which is the real thing and which is the image, and to settle for an ever-expanding choice of images". Rorty, in other words, seems to solve the representationalist dualism by getting rid of only the representation tenet and settling for a monistic solipsism.

Taylor, on the other hand, suggests that there is a place for representation because engagement with reality is possible. He (Taylor, 1995:220) uses the example10 of the difference between Aristotle's view that the sun is a planet and our understanding that the sun is not a planet, to illustrate alternative ways of describing the same reality. These alternative descriptions, he says, can be ranked according to the way they "permit us to grasp, or prevent us from grasping features of reality". This ranking is not "untrivial" because 
the better one gives us a better "handle" on "how things work in our galaxy". 11

Rorty regards representation as "trivial". He (1995:26-27) is aware of the rebuttal of realists who will argue that "although the descriptions may vary depending on the describer, the thing described does not". Therefore, so goes the realist argument, we shall have to make room "for the traditional dualisms" because we should have "a clue to what is real rather than apparent". Rorty answers that he will simply "evade this question" and not fall in his "opponents' trap by taking seriously problems which owe their existence to the scheme/content distinction". He will rather shift "the burden of argument" to his opponents by asking them to indicate the "way of getting between language and its object ... in order to suggest some way of telling which joints are nature's ... and which merely 'ours'”. If they cannot give an indication, he cannot see any point in the claim that some descriptions correspond to reality better than others.

In a recent round in their ongoing debate Taylor (2003:158-159) remarks that Rorty is a "minimalist" who wants to simply walk away from the representationalist picture while Taylor himself is a "maximalist" who thinks it is not possible to only walk away from it all. If you do not identify, work through the issues, and see where they went wrong, you will remain the captive of the representationalist picture.

This ongoing captivity seems true when Rorty (1991:100-101) senses that there is "something dubious" about the idea that there is nothing else to do but to "rearrange our mental representations into pleasing or useful patterns"; that the knowing process is only a search for a "coherent set of beliefs". He knows that he will be accused of solipsism; that if he gives up "the notion of representing objects" he never gets "outside his own head". He accepts that what he has been saying "amounts to accepting this gambit" but he emphasises that this is "all anybody can do". He nevertheless tries to say that his solipsism is not as bad as it sounds because one of his "more central, difficult-to-imagine-revising beliefs" is that objects

11 Taylor (1989a:58, 72) formulates the same idea with regard to moral principles in what he calls the BA (best-account) principle. This principle implies that we make sense of life in terms of certain concepts "unless and until we can replace them with more clairvoyant substitutes". The aim of this principle is to show "not that some position is correct absolutely, but rather that some position is superior to some other". 
he does not control are continually causing him to have new and surprising beliefs. He therefore claims that his anti-idealistic sentiment means he "believes, as strongly as does any realist, that there are objects which are causally independent of human beliefs and desires". He nevertheless adds that an acknowledgement of independent objects "is all that is required to satisfy our realistic intuitions". An extra-interpretation reality is not that important because we "are not also required to say that our descriptions represent objects". Representation is simply "a fifth wheel".

This low-key realism creates the suspicion that Rorty still thinks of perspectives as pointing to something outside the perspective although he believes that contact with this outer world is not important or even possible.12 Rorty's perspectivism, like representationalism, creates the dualist image of two independent and irreconcilable entities; a reality out there does exist but the only things we are able to know are our perspectives. His emphasis on the solipsist side furthermore implies that Rorty's dualism is hierarchical; solipsism gets the higher position. This is of course the opposite of representationalism's dualism which gives the element of representation the higher position but nevertheless is haunted by the possibility of pure solipsism.

A third condition for an epistemology of engagement should thus read as follows: If we want to avoid the looming solipsism of representationalism and perspectivism, we need to find a way that bypasses the dualism (non-contact) between representations/ perspectives and the things about which we have these representations/perspectives. We need, in other words, a view in which representations and perspectives fundamentally or in principle are in contact with reality.

\section{Representation/perspective without the disengaged self}

The motivation behind Rorty's resistance to representationalism seems to be a monistic perspectivism which comprises anti-realism and solipsism. These two components of his monism interact with a third, that is the idea of a self-creative human being that needs to distance itself from any determining extra-self realities.

12 Holówka (1991:190-191) and Gutting (2003:55) also criticise this ambiguity, inconsistency or dualism in Rorty's reasoning. 
True to his anti-essentialism Rorty (1999:52) emphasises that humans have no intrinsic nature, there is no unchangeable human essence that makes humans different from the rest of the universe. $\mathrm{He}$ thinks that being human merely indicates an "open-ended notion"; "a fuzzy but promising project rather than an essence". However, despite this rejection of any inherent nature, Rorty assumes two crucial abilities for humans.

Rorty's perspectivism depends for a large part on the fact that he (1999:64-65) is "happy to admit that human beings are unique in a certain respect: that ... human beings are able to use language, and so are able to describe things". Rorty tries to keep this emphasis within the bounds of his anti-essentialism by connecting our linguistic abilities with Darwin's historicism. Our capacity to use language, he says, simply means that we acquired "more of the sort of cunning which the lower anthropoids had already manifested". He also argues that language does not have an intrinsic nature. He insists that it is only a tool for coping with objects (i.e. not a tool for representation or with which one gets "closer to the intrinsic nature" of something).

Nevertheless, although Rorty tries not to elevate language to the status of human essence, he at least regards language as a crucial human ability. Our relative greater success than that of other animals is because of this ability.

There is, however, a second related ability of which one gets the impresssion that it moves even closer to the taboo of human essence in his thinking. He promotes a creative (through the language ability) rather than a knowing self.

Rorty (1999:34) urges us to stop worrying about the wellgroundedness of beliefs and start being concerned about imaginative alternatives to these beliefs. This, he says, is to substitute a search for "the eternal" with a project of "self-creation on a communal scale". In reaction to Taylor, Rorty (1995:20) says that "one of the most important changes for the better in recent centuries is our increasing willingness to see our poets as edifying examples of how to be mere human self-fashioners, rather than as people who open us up to something other than themselves, and perhaps other than human". He therefore questions Taylor's "conviction that "the poet' ... is pointing to something - God, the tradition". Rorty believes we should "swing free of any such universalistic belief". 
This self-creative view of the human being is, however, not entirely new. According to Taylor (1989b:465-472) it started with Descartes' introduction of the idea that certainty is generated by the mind and not given by the cosmic order. The mind therefore "requires a reflexive turn"; it has to investigate carefully the reliability of its own functioning. This requirement has the consequence "that our thought about the real can be distinguished from its objects and examined on its own". The latter disconnection produced a dualism not only between knower and known but also between the self and its environment. The belief that flows from this view is that which Taylor calls the disengaged self, which appears in representationalism in the guise of the solipsist self. This is the subject that is free and rational to the extent that it has fully distinguished itself from its natural and social embeddings. This view has originally appeared in classical dualism implying that the subject withdraws even from its own body in order to look on it as object.

Taylor is fundamentally sceptical about this view of the self's relation to reality. Descartes, Taylor (1989a:156-160,167-168, 97-198) says, argued that we should not be seen as attuned to the cosmic order or God, but rather that our lives are shaped by the orders that we solipsistically construct according to the demands of reason. This view presupposes that rationality is not defined primarily substantively, but rather procedurally. This view requires a turn to the inner self where certainty is generated "by following the right method". The motive for this move has a lot to do with control and an emphasis on what Taylor calls the "poetic" powers of the self. In fact, the fascination with our poetic capacities "rises at times almost to obsession in our century". What one finds in this respect is the growing ideal of a human agent who is able to remake himself and his world by methodical action. This ideal started with the idea that knowledge comes not from connecting the mind to the order of things, but representing reality according to the right procedures. This approach, however, regards our knowledge of things as our own construct. It was literally thought that our world picture is the putting together of building blocks that consist of the sensations or ideas produced by experience.

Disengagement from an order of things can thus be seen as a serious problem within the representationalist view because it tries to escape our fundamental embeddedness in the world. This problem is, however, equally true of Rorty's perspectivism which also assumes a self-creativist self. Rorty tries to escape this accusation. He (1999:xxi-xix, xxii) simply wants to walk away from 
the distinction between the "found and the made" because this concept has been created by Greek-Christian tradition with a certain utility in mind. Today we do not have these goals in mind. The most important question is therefore to ask what the utility of a particular vocabulary entails. Rorty cannot see any use for the find-create distinction, and therefore hopes to replace it with a distinction between "the more useful and the less useful". This emphasis on utility as alternative for the find-create dualism is, however, in conflict with the emphasis he attached to self-creation as mentioned earlier. His solution thus appears to be a monism in which one side of the dualism ("the found") is simply discarded.

From this critique on a monism in which one aspect is discarded follows at least two important conditions for an engaged process of knowing.

\section{- Knowing reality is important}

The first links with Gutting's (2003:57-58) view that Taylor's substantive approach implies that we are inescapably in contact with the world outside us and even know specific things about it. Gutting calls these "specific things" "baseline, humdrum truths". Although these truths can and should be criticised we "always start inquiry and reflection" from them. Moreover, he says, if we accept this approach, we will be able to avoid many of Rorty's dubious formulations like his avoidance of knowing truths about the world and his attempt to replace it with group consensus. This approach leaves him weak before the charge of "incoherent relativism and scepticism". The latter will "dissolve once we accept humdrum realism".

For Van Woudenberg (1996:79-80) this substantive approach puts ontology before epistemology, and our "everyday" experience before theoretical knowledge. I would rather see an equality and interaction between ontology and epistemology because the two disciplines usually influence and enhance each other - and this is most probably also true of the relation between "everyday" knowledge and theory. (I will elaborate on these relations of interaction, where one discipline or kind of knowledge cannot be foundational for the other, in the next section.)

Nevertheless, an important fourth condition for the process of knowing is that knowledge cannot proceed from representationalism's or perspectivism's purely self-creativist self, for such a self denies our fundamental embeddedness in reality and thus 
makes the idea of knowing obsolete. Positively stated: Knowing or finding the truth about reality is important because we are embedded in a reality that crucially influences our functioning in it.

\section{- The structures of reality enables and necessitates knowing}

The idea of an inescapable engagement with reality as well as his mentioning of a cosmic order brings us to a second implication of Taylor's notion of engagement. Dreyfus (2004:67-77) argues that "Taylor's novel approach" includes that we get "in sync with the structure of the universe the better to cope with it".

Dreyfus refers to Taylor's (2003:170-171) example of telling Johnny to go into a room to see if the picture in it is crooked. Johnny does not verify the belief that the picture is crooked with his own belief about the picture. What is at stake in Johnny's knowing is "causal contact with the world" as well as "certain procedures and standards of justification". With the latter Taylor has in mind Johnny's ability to deal with things. Johnny knows for instance what is the correct distance and orientation to stand in front of the picture.

The latter is a strong suggestion of a structure for the world and our knowing abilities. Thus, although Taylor does not go as far as to positively state that reality has a structure, it is not far-fetched to also see in Taylor's account the assumption of causal structures in the universe that influences our knowledge of the universe. This assumption is for instance also strongly suggested in the idea of an "import"13 that is part of the knowable about which we cannot be neutral. The importance of a structure for reality, Dreyfus (2004:77) remarks, is that "the universe solicits us to get a better and better grip on its causal structure, and rewards us with more and more successful coping".

A fifth condition for an epistemology of engagement can thus be formulated as follows: The fundamental embeddedness of the self in her world assumes a structure for human abilities and reality that enables and necessitates engagement (knowing).

\section{6. "Living with things"}

Taylor's argument for engagement with an extra-self reality does not assume a grasp of reality in an absolute sense. He even introduces

13 Discussed in section 3 on "Reality without the unknowable". 
a somewhat perspectivist outlook. Taylor (1985b:17-21) says for instance that if someone does not agree with your interpretation, you have to show him/her by means of other expressions why your interpretation should be preferred. This view is a circle in the sense that what we appeal to as our grounds for a particular interpretation can only be other interpretations. Sometimes the "scientific" demand seems to be that we reach "a level of certainty which can only be attained by breaking beyond the circle". However, argues Taylor, for his approach the concept break-out is not well-chosen; his idea is rather that understanding must bring an issue to "an inner clarity which is absolute". This is to clear up a meaning that was originally confused, fragmentary and cloudy. Taylor thus sees a "successful interpretation" as one that provides interpretations until you convince the other party.

Despite this seemingly perspectivist portrayal of knowing Taylor maintains a moderate realist position; he tries to give a place to both interpretation/perspective and connection to reality. All of this may seem like a dialectical jumping between interpretation and connection, and thus like a dualism that lingers in his thinking. Others also sense this ambiguity. Dreyfus (2004:63-65) remarks that it may seem that Taylor does not really deviate from Rorty who largely ignores independent realities with the argument that it is more useful to be busy with ideas and beliefs. Brown (1989:112) indeed thinks that Taylor is still the captive of a solipsist epistemology. It is nevertheless clear that some degree of connection with and even representation of reality outside perspective is possible in Taylor's thinking, and regarded as important despite the influence of the perspectivist paradigm in the current intellectual climate. How is this dual claim (perspective as well as connection with reality) to be justified without falling back on the dualism of representationalism?

According to Dreyfus (2004:66) Taylor's "original move" that diverges from Rorty's position is the claim that we cope and are in touch with reality in a way that is more basic than meaning-giving. This basic involvement is actually the engagement on which significance depends.

Taylor uses the Heideggerian concept of pre-understanding to express this idea. Pre-understanding, he says, is knowledge we have before any formulation of how we deal with things (Taylor, 1980b:28). Language does not play a direct role in preunderstanding. Taylor gives the example of feeling uncomfortable in some conversation. When one finally articulates that one feels 
uncomfortable because of jealousy one has the sense that it was not as if there was total ignorance of this emotion before articulation. The inarticulate knowledge "has a kind of intermediate status between known and quite unknown". Through language humans have the capacity to focus on things and identify an object as something that "bears a description X". But usually we live in the world and deal with it without this focusing and conceptualisation (Taylor, 2003:163-164).

A second feature of pre-understanding is that it makes sense of our focused conceptualisations because it provides a "background sense of reality" (Taylor, 1993:325-326). Our formulations (scientific or otherwise) can never exhaustively express our preunderstanding. The relation is rather the other way round; preunderstanding is that in virtue of which we know that our formulations are true or false. We also need to keep in mind that any attempt to articulate this background fully will be futile because articulation itself would rely on a background or horizon of "nonexplicit engagement with the world". In other words, we "cannot turn the background from which we think into an object for us" (Taylor, 1989b:476-477). ${ }^{14}$

Taylor (2003:162) insists that this version of pre-understanding is not a "mediational" grasp of the world. The mediational grasp is the idea that all knowledge "comes through something 'inner', within ourselves or produced by the mind". In the later more sophisticated linguistic turn the inner producer is our language ability that portrays representations no longer as ideas but as sentences. Important in all these versions is an "Inside/Outside" (or "I/O") notion which relies on the understanding that our "grasp of the world" is something that is "in principle separable from what it is a grasp of".

Taylor invokes the Heideggerian notion of "being-in-the-world"15 to rebut the idea that we "can draw a neat line between my picture of an object and that object". A neat line between my "dealing" and the "object" may seem possible when one has beliefs about a football in the absence of the ball. However, when it comes to playing football, it cannot be done without the ball (Taylor, 1989b:476-477). Another

14 Cf. Taylor (1993:328-329; 1991:270) for other apressions of these notions.

15 Taylor (1993:318) argues that for Heidegger the ideas of "being-in-the-world" and "engagement" imply that "the word of the agent is shaped by his or her form of life, or history, or bodily existence". 
example is the ability to move round in the city. In this case one cannot say that knowledge exists in my body apart from my actually moving in the city. The locus of the ability to move round is in my "body-walking-the-streets", and not some potentially disengaged body part (Taylor, 2003:163). These examples say that our "grasp of things is not something that is in us, over against the world; it lies in the way we are in contact with the world" (Taylor, 2003:167).

For Taylor (1989b:477), therefore, our understanding of the world is not based on representations, that is, "depictions that are separately identifiable from what they are of" (Taylor, 1989b:477), but in a "living with things" (Taylor, 2003:163). Important to note is that he (Taylor, 1989:476) thinks that even the "condition of our forming disengaged representations of reality is that we be already engaged in coping with our world, dealing with the things in it". In other words, even in our disinterested, theoretical stance towards the world "we have to come to grips with it" which assumes "we are engaged as agents coping with things". Taylor's exposition of his antirepresentationalism with the concepts pre-understanding and "living with things" should thus not leave the impression that it excludes representations.

Nevertheless, a sixth condition for knowledge (including our representations) should assume that knowledge is not something that can be created by the knowing abilities of the knower independently from the knowable. Knowledge comes into being in the act of engagement between knower and known.

\section{Engagement without foundationalism}

Taylor's view that pre-understanding precedes our focus and articulation of things, however, needs careful formulation because it can be susceptible to foundationalism.

Rorty (1999:34-35, 37) explains that if we see our beliefs as justified, it is a "consequence of the holistic character of belief-ascription". A meaningful belief has connections with other meaningful beliefs. If it cannot cohere with other beliefs, it will be seen as an unjustified belief. There are thus no "foundational" concepts of knowledge like the rationalist "natural order of reasons" or the empiricist "deliverances of the senses" that can be used in a context-free justification of beliefs. It is nevertheless important to note that the "whole" that Rorty refers to, is regarded by him as an intra-human system of beliefs and sentences that does not necessarily engage with a reality outside this web. 
Taylor (2003:160) shares with Rorty the rejection of foundationalism; that is, the project of building a "principled justification of our beliefs about the world from the ground up". This anti-foundationalism also implies that claims cannot be verified each on their own. But, Taylor says, this is where Rorty's holism ends because he still seems to accept the "Cartesian-empiricist doctrine of the atomism of the input". Taylor (2003:162) seems to imply that according to Rorty perceptions and ideas only take a holistic interdependent mode once they appear inside the knower's linguistic representations. This leaves the idea in place that an agent's knowledge is distinct from the world. Taylor (2003:160) wants holism to be more radical than this by seeing any single element always in a larger whole in which its meaning is defined. There is no such thing as the single independent perception. Something is a perception only within a wider context.

Rorty, however, appears to agree with Taylor. Rorty (1999:xxii-xxiii) too rejects the $1 / O$ picture which, in his opinion, means that there is no possibility that words "can take one out of touch with reality". Words/statements are tools (like e.g. a hammer) which we use to interact with our environment. Representationalism, on the other hand, will prompt us to ask the "question of whether human minds are in touch with reality" because it wants to represent the "intrinsic nature" of our environment. According to Rorty this question cannot be asked because there is no way we can have a "Cartesian picture of a mind which somehow swings free of the causal forces exerted on the body". This statement of belief in a fundamental engagement between humans and their environment is of course one of those rare moments when Rorty steps out of the solipsism of his usual perspectivism.

According to Taylor pre-understanding precedes and forms the basis for focused knowing and articulations. This may give preunderstanding the image of the "foundation" of our knowing. It is nevertheless important to keep in mind that Taylor assumes a "radical" holism in which everything receives its meaning from the larger whole.16 In order to be consistent Taylor's idea of pre-

16 This is an important point that is also acknowledged by others. Toulmin (1992:199-201) for instance argues against the modernist ideal of a rational method that could cut away the "inessentials" and identify the "abstract core of 'clear and distinct' concepts". This ideal, however, will not solve any real-life problems, he says. What we need is to re-contextualise (re-engage) what we know - especially by putting it in the "larger human frame". 
understanding should then also receive meaning from focused knowledge; our acts of meaning-giving, representation, articulation and focus also inform our pre-understanding. There is no foundationalist one-way movement from pre-understanding to representation but a mutual moulding of each other. It should therefore also be possible to speak of acts of representation as my "mind-grasping-this-object". In this formulation the intention is not to shape representations out of perceptions, ideas or preunderstandings that exist atomistically, independently and which can be used as the foundations from which the mind or language is able to build a body of knowledge.

A seventh condition for knowing as engagement: Knowing reality proceeds in an anti-foundationalist way. This implies an ongoing process of interaction between my abilities to engage with reality and the objects of knowing that stimulate my abilities of knowing.

\section{Multi-mode knowing and the multi-functional knowable}

Rorty's critique of modernist epistemology is primarily directed to the problem of foundationalism and he seems not to be particularly concerned about the solipsism and thus disengagement that are endemic to representationalism. Taylor's criticism of representationalism, however, is primarily directed to this weakness of the modernist epistemological enterprise. 17 Therefore, although he acknowledges and explores the huge influence of human perspectives on human knowledge, he also tries to find ways for these perspectives to engage with the extra-perspective world. Especially important is his argument that contact between the world and our perspective is facilitated by our pre-understanding which lies midway between knowledge and a non-focused dealing with the world.

The idea of a pre-understanding has two crucial implications.

- Firstly, the moment one starts to know, as well as during the entire knowing process, one deals also with the knowable. The and Taylor. 
knower is not in a position where she knows only representations, perspectives and interpretations.

- Secondly, a knower's ability to form a pre-understanding not only involves her senses and rational capacity but more abilities of grasping reality are needed in order to get the broader background of the world in which she wants to know her way. This ability is an important intuition because supporters of representationalist epistemology tend to recognise only the mind and sense experience as knowing abilities. ${ }^{18}$

The latter idea of a multi-mode knowing of pre-understanding becomes clear in a recent account of Taylor's idea of preunderstanding. In his latest exchange with Rorty, Taylor (2003:159, 161) argues that pre-understanding includes a host of abilities to cope with the world. He names our bodily capacity to find our way in our physical surroundings, our social intuition on how to relate to and interact with others and also the beliefs we hold, "which may or may not be 'in our minds' at the moment". He accuses "intellectualism" of making us see these abilities as "very different sites". The anti-representationalist tradition, however, "has shown how closely akin they are, and how interlinked". He nevertheless insists that these capacities precede representations in the form of articulations; that they only inform the inarticulate background that allows the representations that we do form.

Rorty (1995:31-32) acknowledges that Taylor's idea of preunderstanding means that he "sees a more primordial relation with the world than representation". He nevertheless accuses Taylor of still assuming a divide between this primordial relation with the world and language. Rorty, on the other hand, claims that he sees "no break between non-linguistic and linguistic interactions of organisms (or machines) with the world". He therefore cannot see "our nonlinguistic causal interaction with the rest of the universe as 'grounding' knowledge" because "formulating and verifying propositions" are "just a special case of what Taylor calls 'dealing' and I call 'coping'”.

18 According to Van Woudenberg (1996:76-77) it is crucial for supporters of the epistemological tradition that they claim to be sure about the sources for knowledge and then reduce these sources to sense experience, memory, consciousness and reason. In other words, conformation to only these sources of knowledge is the criterion for true knowledge. 
At another place Rorty's $(1999: 55-57,59)$ critique becomes clearer. He states that it is especially essentialists who argue that language is not our only cognitive access to objects. Essentialists think some "prelinguistic knowledge" of things does exist, knowledge that cannot be caught in language. The essenstialist, he says, will demonstrate this prelinguistic knowledge by banging on the table and will cringe to demonstrate that he has acquired a bit of knowledge that escapes language. Rorty is not convinced that this non-linguistic way of knowing gives a more intimate kind of knowledge. He thinks that all you will gain is more statements about the table. At this stage you will be able to say that the table is brown, ugly, and will cause pain if one bangs on it. One does not get more intimate knowledge of the number 17 by working out its square root. Similarly one does not get closer to the "intrinsic nature" of a table by banging on it. Hitting merely relates the table to a few more things. It does not take you "out of language into fact".

Once again one gets the impression that Rorty too quickly tries to pin essentialism on Taylor and that he allocates an inflated role to language and perspective. To see ways of "being aware of something" other than articulation does not mean that one tries to break through to some essence. Rorty may, nevertheless, be onto something that Taylor does not get right if he suggests that linguistic representation is not a secondary act that follows only after some foundational pre-understandings. Taylor and Rorty's views should be amended to state that it is possible to see articulation as an act of knowing on an equal footing and in co-operation with other acts of knowing. Rorty should thus rather make more of the idea that, like articulation as a specific way of coping with the world, there are also others. But then again, Rorty fails to recognise that Taylor's notion of pre-understanding points to kinetic, sensory, reasoning, emotional, social sensitivity, as well as meaning-giving ways of experiencing the world.

Rorty concentrates on the idea that there are no linguistically unmediated perceptions or ideas that can serve as foundations for the creation of representations in the human mind or in language. He suggests that knowledge almost always implies merely beliefs, interpretations or perspectives that are determined by our goals for using these ideas. It is however, doubtful whether we should go as far as Rorty who strongly tends towards enclosure in perspectives that rarely care to make contact with the extra-perspective reality.

An important condition for Rorty's perspectivism is an anti-realist ontology which targets especially the existence of essences. He 
argues that if essences are in principle not knowable, as it is usually presented, it will be nonsensical to try and know and represent it. Rorty is of course correct that the problem with representationalism is also that it assumes unknowable essences or substances. Rorty's (1999:47) aim to "shake off" metaphysical dualisms like essence and accident as well as substance and property, can be supported. In its place he proposes a "panrelationalism", which, he believes, implies the meaning that reality consists of "a flux of continually changing relations". The implication of this proposal is that a diversity of relations among things can be known. Rorty's thinking thus inadvertently makes room for an extra-perspective reality that can be known. Taylor is therefore correct to argue that it is not necessary to identify all objects of knowing with unknowable essences.

Rorty's assumption of the non-durability of relations is, however, suspect. He seems to suggest that the "fixed" parts of the dualisms he rejects (essence, substance) should be dropped and we should invest only in the "fleeting" parts (accident, property) which he identifies with relations. This monistic choice for a mere fleeting reality would be incoherent even in his own terms. This incoherence can be illustrated in his description of the number 17 as example of his panrelationism.

The nice thing about numbers, Rorty (1999:52-53) says, is that it is difficult to think of them in terms of essences. The number 17 cannot be described except in terms of its relationships to other numbers: it is a number less than 22, the sum of 6 and 11, and so on. What Rorty hopes to achieve with this example is to convince people that there are no essences to be found, and that one can equally not be an essentialist about tables, stars, human beings, academic disciplines, social institutions or anything else. There is nothing to be known about things except a "forever expandable web of relations to other objects".

Rorty's pan-relationism is onto something in the sense that he does not try to identify one single function or relation to which an object can be reduced. However, the impression he creates that this plurality and interconnection of relations also mean that there are no significant durable structure for things, and that this lack implies that knowledge of things are superfluous, is simply not true. That 17 follows upon the number 16 , and that it is the sum of 10 and 7 were true two thousand years ago, and it will probably be true for times to come. Rorty will argue that the number 17 is recognised as 17 because of human needs and interests. But, he will say, our needs 
can change. Moreover, extra-terrestrials or animals will not have a concept of 17 because their needs are different. The implication is that 17 is human-dependent; there is no 17 apart from human needs. 19 To this view, two rejoinders can be put forward. Firstly, we can emphasise the relation between 17 and 10 more than the relation between 17 and 7 because of our contingent needs and desires, whatever they may be. These needs and desires, however, do not render the relation between 17 and 7 null and void. The latter relation is still there despite our needs, and because the structure of relations for numbers remains intact. The argument Taylor will most likely put forward is that if we decide to change our description of 17 and its relations, we will probably do it because we think the new description will give us a better grip on reality. This description will, however, merely prove the point that the way things are outside our system of beliefs (perspective) will be important in our decision.

Rorty's pan-relationism is not really an argument to escape a side of reality that can be called its relational and functional structure. And it is important to know it, for if we do not even know that 17 follows upon 16 , or that it is the sum of 10 and 7 , then we know nothing about 17 and we should conclude that it does not exist.

The strong point of Rorty's pan-relationism is that he makes room for the knowing of a multitude of relations between things. What he does not acknowledge is that the structure of these relations are important to know because they are able to influence the goals and interests of people with things fundamentally. Despite his intention to simply walk away from epistemology and rather concentrate on selfcreation, Rorty stumbles over an important side of the process of knowing, that is, the multi-functional and multi-relational structure of the knowable.

What Rorty does for the knowable, Taylor does for the knower. In his attempt to show that a direct grasp of the knowable is possible and fundamental, he seems to be in danger of becoming a foundationalist. He nevertheless makes it possible to see the importance of a multi-mode knowing structure for knowers.

19 Cf. the example Rorty (1999:xxvi) gives of the concept giraffe. We use languages that include this word and fit our needs or interests. We therefore recognise giraffes because we have a word for it and because we want to hunt them. But if one is an ant or space voyager, the latter meaning attached to giraffe will not necessarily be their tool of recognition or need, and chances are that they will not see giraffes as we see them. 
In conclusion: Rorty and Taylor arrive at what can be called a "thick" process of knowing, which contrasts with the "thinness" of representationalism with its emphasis on only representations.

An eighth condition for knowing as engagement thus states that we live in a world in which knowing takes place between a knower with multiple abilities to engage with a knowable of which we are able to know a variety of functions and relations between these functions.

\section{List of references}

BRAECKMANS, L. 1997. Charles Taylor, metafysicus na het postmodernisme? (In Cuypers, S.E. \& Lemmens, W., red. Charles Taylor: een mozaïk van zijn denken. Kapellen: Uitgeverij Pelckmans. p.167-174.)

BROWN, R. 1989. Review of "Human agency and language, philosophical papers". Philosophy of the Social Sciences, 19(1):109-115.

DREYFUS, H.L. 2004. Taylor's (anti-) epistemology. (In Abbey, R., ed. Charles Taylor. Cambridge: Cambridge University Press. p. 52-83.)

GUTTING, G. 2003. Rorty's critique of epistemology. (In Guignon, C. \& Hiley, D.R., eds. Richard Rorty. Cambridge: Cambridge University Press. p. 4160.)

HOLLIS, M. 1991. The poetics of personhood. (In Malachowski, A.R., ed. Reading Rorty: critical responses to "Philosophy and the mirror of nature" and beyond. Oxford: Blackwell. p. 244-256.)

HOLÓWKA, J. 1991. Philosophy and the mirage of hermeneutics. (In Malachowski, A.R., ed. Reading Rorty: critical responses to "Philosophy and the mirror of nature" and beyond. Oxford: Blackwell. p. 187-197.)

RORTY, R. 1980. A reply to Dreyfus and Taylor. Review of Metaphysics, 34(1):39-46.

RORTY, R. 1991. Objectivity, relativism, and truth: philosophical papers. Volume 1. Cambridge: Cambridge University Press.

RORTY, R. 1995. Taylor on truth. (In Tully, J., ed. Philosophy in an age of pluralism: the philosophy of Charles Taylor in question. Cambridge: Cambridge University Press. p. 20-33.)

RORTY, R. 1999. Philosophy and social hope. London: Penguin.

SLORS, M. 1995. Realisme zonder representatie. Algemeen Nederlands Tijdschrift voor Wijsbegeerte, 87(1):15-32.

TAYLOR, C. 1980a. Taylor's comments. Rorty, Taylor, and Dreyfus: a discussion. Review of Metaphysics, 34(1):47-55.

TAYLOR, C. 1980b. Understanding in human science. Review of Metaphysics, 34(1):25-38.

TAYLOR, C. 1985a. Philosophical papers. I: Human agency and language. Cambridge: Cambridge University Press.

TAYLOR, C. 1985b. Philosophical papers. II: Philosophy and the human sciences. Cambridge: Cambridge University Press.

TAYLOR, C. 1989a. Sources of the self: the making of the modern identity. Cambridge: Cambridge University Press. 
TAYLOR, C. 1989b. Overcoming epistemology. (In Baynes, K., Bohman, J. \& McCarthy, T., eds. After philosophy: end or transformation? Cambridge: MIT. p. 464-488.)

TAYLOR, C. 1991. Rorty in the epistemological tradition. (In Malachowski, A.R., ed. Reading Rorty: critical responses to "Philosophy and the mirror of nature" and beyond. Oxford: Blackwell. p. 267-275.)

TAYLOR, C. 1993. Engaged agency and background in Heidegger. (In Guignon, C.B., ed. The Cambridge companion to Heidegger. Cambridge: Cambridge University Press. p. 317-336.)

TAYLOR, C. 1995. Reply and re-articulation. (In Tully, J. \& Weinstock, D.M., eds. Philosophy in an age of pluralism: the philosophy of Charles Taylor in question. Cambridge: Cambridge University Press. p. 213-257.)

TAYLOR, C. 2003. Rorty and philosophy. (In Guignon, C. \& Hiley, D.R., eds. Richard Rorty. Cambridge: Cambridge University Press. p. 158-180.)

TOULMIN, S. 1992. Cosmopolis: the hidden agenda of modernity. Chicago: The University of Chicago Press.

VAN WOUDENBERG, R. 1996. Theorie van het kennen. (In Van Woudenberg, R., red. Kennis en werkelijkheid. Kampen: Kok. p. 21-85.)

WOLTERS, A.M. 1988. Creation regained: Biblical basics for a Reformational worldview. Grand Rapids: Eerdmans.

\section{Key concepts:}

foundationalism

pre-understanding

representationalism

Rorty, R.

solipsism

Taylor, C.

\section{Kernbegrippe:}

fondamentalisme

representasionalisme

Rorty, R.

solipsisme

Taylor, C.

voor-verstaan 
